\title{
Role of CRP in Lower Respiratory Tract Infections
}

\author{
Kaur $\mathbf{J}^{1}$, Narang $\mathbf{G S}^{2}$, Arora $\mathbf{S}^{3}$ \\ ${ }^{1}$ Dr. Jaskaranjot Kaur, MBBS, MD, Resident, ${ }^{2}$ Dr. \\ Gursharan Singh Narang, MBBS, MD, Professor of \\ Paediatrics, ${ }^{3} \mathrm{Dr}$. Sunita Arora, MBBS, MD, Associate \\ Professor. All from the Department of Paediatrics, \\ Sri Guru Ramdas Institute of Medical Science and \\ Research, Amritsar, Punjab, India.
}

\section{Introduction}

C reactive protein (CRP) is an acute phase protein that increases on inflammatory triggers and decreases rapidly with resolution of inflammation. It is synthesized and secreted by the liver in response to inflammatory cytokines, particularly $\mathrm{IL}-6$ and others such as tumour necrosis factor (TNF), IL-I and transforming growth factor ${ }^{1,2}$. CRP synthesis increases within 4-6 hours of an inflammatory trigger and doubles every 8 hours. It peaks at 36 to 50 hours $^{3}$. The ability to measure CRP quickly and quantitatively has made it increasingly useful in clinical practice. The definition of the presence, the aetiology and the severity of lower respiratory tract infection (LRTI) as well as the treatment choice and duration are frequently a real problem for the treating physician. Clinical features are sometimes misleading and not specific varying according to the aetiology (bacterial or viral), virulence, and adequacy of host response and presence of concomitant diseases. The aetiology is also poorly established due to inadequate patient definition and limited pathogen detection (16-55\%) resulting from a combination of inadequate clinical sampling and pathogen detection methodology, particularly for respiratory viruses ${ }^{4,5}$. Excessive use of antibiotics is the main cause of the spread of antibiotic-resistant bacteria ${ }^{6,7}$. Thus, avoidance of irrational antibiotics is essential to combat emergence of antibiotic-resistant micro-organisms ${ }^{8,9}$. In view of this diagnostic and therapeutic dilemma, a more reliable test for the differential diagnosis of bacterial respiratory tract infections in need of antibiotics from other respiratory disease would be extremely helpful ${ }^{10}$. There is a clear need for diagnostic and prognostic biomarkers in LRTIs. The aim of this study was to find out about the role

\section{Address for correspondence}

Dr. Gursharan Singh Narang

Prof. and Head of Department, Department of Paediatrics, Sri Guru Ramdas Institute of Medical Science and Research, Amritsar, Punjab, India.

E-mail: gsnarang@gmail.com

\begin{abstract}
Introduction: Better diagnostic tests that establish the cause of LRTIs can reduce irrational antibiotic use. CRP is an acute phase protein that increases on inflammatory triggers can solve the purpose. The study aimed at role of CRP in distinguishing between bacterial and viral etiology. Materials and Methods: Fifty patients, aged 2 months to 5 years, with complaints of fever, cough and respiratory distress were included. Along with all other basic investigations like CBC, PBF, ESR, CRP Quantitative was also by Nycocard CRP Single Test for in vitro rapid determination. Results: In LRTI of probable bacterial aetiology mean CRP was $61.72 \pm 36.665 \mathrm{mg} / \mathrm{l}$ which was significantly higher than those with probable viral aetiology with mean CRP of $5.24 \pm 1.4 \mathrm{mg} / \mathrm{l}$. The cut off level of CRP is taken as $9 \mathrm{mg} / \mathrm{l}$ with sensitivity of $100 \%$ and specificity of $96 \%$. Conclusion: CRP levels are both sensitive and specific for differentiating between viral and bacterial LRTI, thus reducing the overuse of antibiotics in clinical practice.
\end{abstract}

Key words: Lower respiratory tract infections, C-reactive protein.

of CRP in distinguishing between bacterial and viral etiology of LRTI

\section{Materials and Methods}

This was a prospective study. The subjects included 50 patients in the age group of two months to five years of either sex with complaints of fever, cough and fast breathing attending the indoor and OPD of the department of Paediatrics of Sri Guru Ramdas Institute of Medical Sciences and Research, Amritsar. Diagnosis of lower respiratory tract infections was made according to WHO criteria. 


\section{Exclusion criteria}

a) Immuno-compromised patients.

b) Patients with congenital heart disease.

c) Patients with congestive heart failure.

d) HIV positive patients

A detailed history and complete clinical examination was done. The subjects were screened for $\mathrm{Hb}$, TLC, DLC, PBF, ESR and Quantitative CRP. Chest X-ray (PA view) was done in all cases and USG or CT chest was done whenever indicated.

CRP was done by Nycocard CRP single test, an in vitro test that is used for the rapid determination of CRP. Nycocard CRP single test is a solid phase, sandwich format, immunometric assay. In this test there is a membrane coated with immobilised CRP-specific monoclonal antibodies. A diluted sample is applied to the test device. When the sample flows through the membrane, the $C$ reactive proteins are captured by the antibodies. CRP trapped on the membrane will then bind the gold-antibody conjugated added, in a sandwich type reaction. A paper layer underneath the membrane absorbs excess liquid. In the presence of pathological level of CRP in the sample, the membrane appears red-brown with colour intensity proportional to the CRP concentration of the sample. The colour intensity is measured quantitatively with the NYCO card Reader. The data was analysed by chi-square test using SPSS 15.0 version software

\section{Results}

CRP was found to be $61.72 \pm 36.665 \mathrm{mg} / \mathrm{l}$ in patients with bacterial aetiology. And those with probable viral aetiology (e.g. bronchiolitis) had mean CRP of $5.24 \pm 1.411 \mathrm{mg} / \mathrm{l}$. The mean difference was found to be 56.486 and $p$-value is less than 0.001 that is highly significant.

The receiver-operating characteristic curve area under the curve for relative CRP variation was 0.973 $(95 \%$ confidence interval $=0.61-0.86)$. The larger the area, the better is the diagnostic test.
Table 2: Depicting the cut off value of CRP

\begin{tabular}{|c|c|c|}
\hline $\begin{array}{c}\text { Positive if less than } \\
\text { or equal toa }\end{array}$ & Sensitivity & 1 - Specificity \\
\hline 2.00 & .000 & .000 \\
\hline 3.50 & .048 & .000 \\
\hline 4.50 & .381 & .034 \\
\hline 5.50 & .619 & .034 \\
\hline 6.50 & .810 & .034 \\
\hline 7.50 & .905 & .034 \\
\hline 9.00 & 1.000 & .034 \\
\hline 11.00 & 1.000 & .103 \\
\hline 18.00 & 1.000 & .172 \\
\hline 28.00 & 1.000 & .207 \\
\hline 35.00 & 1.000 & .241 \\
\hline 39.00 & 1.000 & .276 \\
\hline 42.50 & 1.000 & .310 \\
\hline 45.50 & 1.000 & .345 \\
\hline 47.00 & 1.000 & .379 \\
\hline 50.50 & 1.000 & .414 \\
\hline 53.50 & 1.000 & .448 \\
\hline 55.50 & 1.000 & .483 \\
\hline 61.00 & 1.000 & .517 \\
\hline 68.50 & 1.000 & .552 \\
\hline 73.00 & 1.000 & .586 \\
\hline 74.50 & 1.000 & .655 \\
\hline 76.50 & 1.000 & .690 \\
\hline 81.50 & 1.000 & .724 \\
\hline 87.50 & 1.000 & .759 \\
\hline 95.00 & 1.000 & .793 \\
\hline 106.00 & 1.000 & .828 \\
\hline 116.00 & 1.000 & .862 \\
\hline 121.00 & 1.000 & 1.000 \\
\hline
\end{tabular}

The cut-off CRP level for differentiating bacterial and viral aetiology on $7.5 \mathrm{mg} / \mathrm{l}$ the sensitivity is $90.5 \%$ with the specificity of $96 \%$. But if we take $11 \mathrm{mg} / \mathrm{l}$ as a cut-off the sensitivity is $100 \%$ but specificity decreases to $89.7 \%$. So we take $9 \mathrm{mg} / \mathrm{l}$ as cut of level of CRP with sensitivity of $100 \%$ and specificity of $96 \%$.

Table 1: Showing the correlation of CRP with bacterial and viral LRTI

\begin{tabular}{|c|c|c|c|c|c|}
\hline Group & $\mathrm{N}=50$ & Mean \pm SD $(\mathrm{mg} / \mathrm{l})$ & Mean difference & 't' value & p-value \\
\hline Bacterial & 29 & $61.72 \pm 36.665$ & \multirow{2}{*}{56.486} & \multirow{2}{*}{7.038} & \multirow{2}{*}{$<0.001^{*}$} \\
\hline Viral & 21 & $5.24 \pm 1.411$ & & & \\
\hline
\end{tabular}

${ }^{*} p<0.001$; Highly significant 


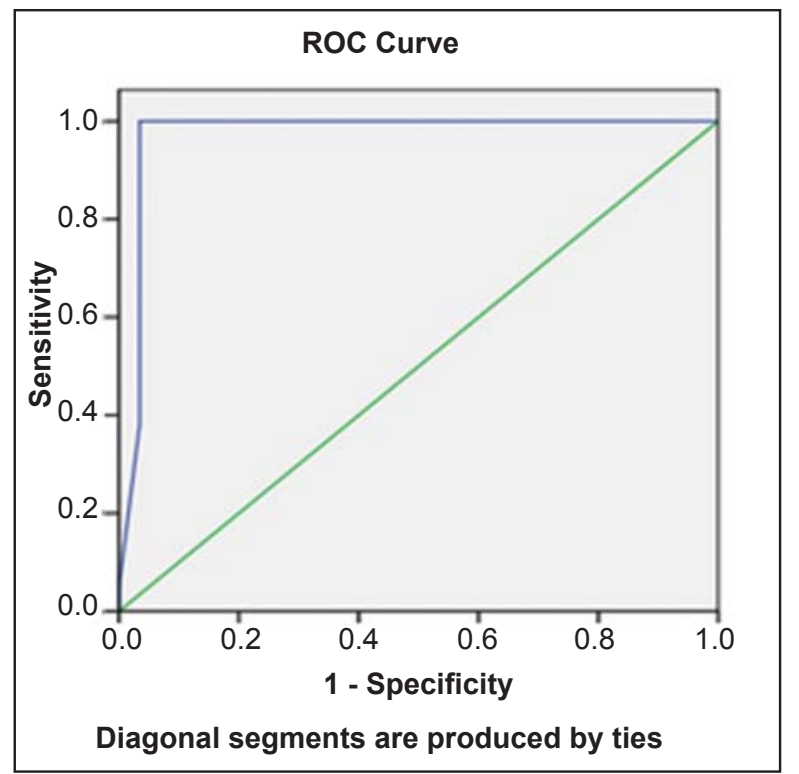

Fig 1: ROC Curve showing sensitivity and specificity of CRP.

\section{Discussion}

Irrational prescription of antibiotics for respiratory tract infections is partly caused by diagnostic uncertainty about aetiology. Tests for $\mathrm{C}$ reactive protein are increasingly used to guide antibiotic prescribing for infections of the lower respiratory tract.

In this study, in LRTI of bacterial aetiology mean CRP was found to be $61.72 \pm 36.665 \mathrm{mg} / \mathrm{l}$ and those with probable viral aetiology had mean CRP of 5.24 \pm 1.411 . Similar observations were made by Smith et al $^{11}$ who observed mean CRP in pneumonia is $217 \pm$ $16 \mathrm{mg} / \mathrm{l}$ and in bronchiolitis mean CRP is $18 \pm 3 \mathrm{mg} / \mathrm{l}$. Though the levels of CRP in our study are lesser than in the study by Smith et al, it could be because of prior antibiotic use, single measurement of CRP in our study, varied time interval of presentation and inclusion only of uncomplicated cases of pneumonia. Flanders et al ${ }^{12}$ also evaluated median CRP levels which were significantly higher for patients with pneumonia than viral LRTI (60 $\mathrm{mg} / \mathrm{l}$ versus $9 \mathrm{mg} / \mathrm{l} ; \mathrm{P}<0.001)$. Dagga et $\mathrm{al}^{13}$ observed that the mean CRP was $75.87 \pm 17.1 \mathrm{mg} / \mathrm{l}$ in patients with pneumonia and $16.71 \pm 20.76 \mathrm{mg} / \mathrm{l}$ in patients with COPD in acute exacerbation. Mean CRP levels were 121.3+/122 and $27.2+/-26 \mathrm{mg} / \mathrm{l}$, respectively in bacterial and viral LRTI in study conducted by Marcus et $\mathrm{al}^{14}$.The study aimed at differentiating bacterial and viral LRTI and CRP levels were higher in former than later.

In present study the receiver-operating characteristic curve area under the curve for relative CRP variation was 0.973 (95\% confidence interval $=0.61-$ 0.86). Lala SG et $\mathrm{al}^{15}$ also assessed the discriminative ability of CRP values by ROC plots in pneumonia and found it to be 0.80 . This was similar to observation made by Flanders et al ${ }^{12}$ who got 0.83 area.

The cut-off of 9 is taken as the best chosen CRP value in this study with $100 \%$ sensitivity and specificity of $96.6 \%$. In a similar study by Pullium et $\mathrm{al}^{16}$ a CRP cutoff point of 7 was determined with sensitivity of $79 \%$ and specificity of $91 \%$. Lala SG et al ${ }^{15}$ concluded that CRP $\geq 10 \mathrm{mg} / \mathrm{l}$ identified $90 \%$ of all bacteraemic pneumonias. The optimal cut off point for CRP $4.4 \mathrm{mg} / \mathrm{l}$ achieved a sensitivity of $63 \%$ and specificity of $81 \%$ for detection of occult bacterial infection in Daniel $\mathrm{J}$ et al study ${ }^{17}$. The difference in the cut off values can be explained by different techniques of CRP measurements used in different studies. Inspite of difference in cut-off values, the sensitivity and specificity is significant to help differentiate bacterial and viral LRTI.

\section{Conclusion}

$\mathrm{CRP}$ is a reliable biomarker to differentiate bacterial and viral LRTI, thus it can empower physicians to safely prescribe lesser and appropriate antibiotics reducing the over usage, toxicity and resistance of antibiotics.

Acknowledgements: None

Funding: Nil

Conflict of Interest: None

Permission from IRB: Yes

\section{References}

1. Clyne B, Olshaker JS. The C-reactive protein. J Emerg Med 1999;17:1019-25.

2. Du Clos TW. Function of C-reactive protein. Ann Med 2000;32:274-78.

3. Ballou SP, Kushner 1. C-reactive protein and the acute phase response. Adv Intern Med 1992;37:313-36.

4. Boldy D A R, Skidmore S J, Ayres J G. Acute bronchitis in the community: clinical features, infective factors, changes in pulmonary function and bronchial reactivity to histamine. Respir Med 1990;84377:385-85.

5. Melbye H, Berdal B P. Akutt bronkitt hos voksne. Kliniske funn, mikroorganismer og bruk av antibiotika [Acute bronchitis in adults. Clinical findings, microbes and antibacterial treatment]. Tidsskr Nor Laegeforen 1994;114814:817.

6. Wenzel RP, Wong MT. Managing antibiotic use -impact of infection control. Clin Infect Dis 1999;28:1126-127.

7. Chen DK, McGeer A, de Azavedo JC, Low DE. Decreased susceptibility of Streptococcus pneumoniae to fluoroquinolones in Canada. 
Canadian Bacterial Surveillance Network. N Engl J Med 1999;341:233-39.

8. Gonzales R, Steiner JF, Lum A, Barrett PH Jr. Decreasing antibiotic use in ambulatory practice: impact of a multidimensional intervention on the treatment of uncomplicated acute bronchitis in adults. JAMA 1999;281:1512-519.

9. Guillemot D, Courvalin P. Better control of antibiotic resistance. Clin Infect Dis 2001;33:542-47.

10. Muller B, Harbarth S, Stolz D, et al. Diagnostic and prognostic accuracy of clinical and laboratory parameters in community-acquired pneumonia. BMC Infect Dis 2007;7:10.

11. Smith RP, Lipworth BJ. C-reactive protein in simple community-acquired pneumonia. Chest 1995;107(4):1028-31.

12. Flanders SA, Stein J, Shochat G, et al. Performance of a bedside $\mathrm{C}$-reactive protein test in the diagnosis of community-acquired pneumonia in adults with acute cough. Am J Med 2004;116: 529-35.
13. Daga MK, Arora N, Prakash SK, Jhamb R, Kumar N, Gupta N. C-reactive protein in lower respiratory tract infections. Lung India 2005;22:41-4.

14. Marcus N, Mor M, Amir L, Mimouni M, Waisman Y. Validity of the quick-read C-reactive protein test in the prediction of bacterial pneumonia in the pediatric emergency department. Eur J Emerg Med 2008;15(3):158-61.

15. Lala SG, Madhi SA, Pettifor JM.The discriminative value of $\mathrm{C}$-reactive protein levels in distinguishing between community-acquired bacteraemic and respiratory virus-associated lower respiratory tract infections in HIV-1-infected and uninfected children. Ann Trop Paediatr 2002;22(3):271-9.

16. Pulliam PN, Attia MW, Cronan KM. C-reactive protein in febrile children 1 to 36 months of age with clinically undetectable serious bacterial infections. Pediatrics 2001;108:1275-279.

17. Daniel J, Isaacman MD, Bonnie L et al. Utility of serum C-reactive protein for detection of bacterial infection in children. Arch Pediatr Adoles Med 2002;156:905-10. 